\title{
Socializing Intellectual Talk: A Case Study of Instructor Follow-Up Statements in Classroom Discourse
}

\begin{abstract}
Caroline S. Parsons ${ }^{1}$
Abstract: By analyzing the audio recording and transcription of classroom discourse, this case study focused on the ways in which the instructor used followup statements to socialize students into intellectual talk. Four relevant categories of follow-up statements emerged: (a) revoicing, (b) contextualization, (c) parallel elaboration, and (d) assistive elaboration. These follow-up statements elevated students' ability to articulate their ideas, restated or contextualized their ideas, and guided them to ground their utterances in the course readings and materials. Another conclusion drawn from the findings is that students clearly became enmeshed in the program's community and were able to demonstrate this membership through their use of intellectual talk in the classroom. Suggestions for future research are provided. Practical recommendations for facilitating active and engaging classroom discourse are provided.
\end{abstract}

Keywords: instructional development, classroom discourse, socialization, student development, higher education, liberal arts classroom, case study, communication education.

The classroom is a site for social interaction and student development. As a culture complete with its own unique language system (Lindsay, 1990), the classroom provides a space in which instructors and students can freely exchange ideas, information, questions, points of clarification, feedback, and dialogue. Classroom interaction and discourse is essential to the teaching and learning process (Cazden, 1988). In the classroom, students and instructors negotiate meaning through discussion, dialogue, and discourse.

As a central facilitator, soliciting questions, responding to questions, and interacting with students, an instructor regulates communication and discourse in the classroom. O'Connor and Michaels (1993) posit that instructors actively facilitate "students' socialization into the roles and identities of intellectual discourse” (p. 318). Through classroom discourse, instructors socialize and assimilate students into one of the primary desired outcomes of classroom discussion: competent and correct usage of talk.

This article investigates instructors' management of extended talk sequences and turntaking, specifically follow-up statements, in a liberal arts classroom at a large university. The study adds to current research on classroom discourse, socialization, and observational research in the area of communication education and instructional communication.

Instructor follow-up statements are an important part of students' socialization into intellectual talk. Follow-up statements are extended turns of talking that occur after an instructor initiates a discussion. Mehan (1979) described the basic structures of classroom discourse (e.g.,

\footnotetext{
${ }^{1}$ Department of Communication Studies, The University of Alabama, 203 Reese Phifer Hall, Tuscaloosa, AL 35487, csparsons@ua.edu.
} 
instruction-reply-evaluation and its extended sequences) as turn-taking utterances that teachers deploy to regulate the flow of classroom discourse and that students' acquire in order to contribute competently to a classroom community.

Follow-up statements act as discourse markers to navigate turns of talking. Turns tend to be reclaimed at transition-relevant moments (Sacks, Schegloff \& Jefferson, 1974). For example, the third or fourth turn in a sequence of participant turn-taking is typically the site for an instructor's follow-up statement. Follow-up statements are central locations in discourse turntaking that provide a rich area for analysis of an instructor's use of socializing discourse.

To explore the socialization of intellectual talk, this study sought to investigate ways in which instructors use follow-up statement to socialize students' intellectual talk on modern university campuses today. This article will: 1) provide a literature review, 2) describe the methodology of the study, 3) present the results and findings, and 4) discuss the relevance and usefulness of the findings.

\section{Literature Review}

Law school classrooms and architecture and design studio classrooms have served as a site for studying classroom discourse and the socializing of intellectual talk and preparation for students' future, chosen professions. Follow-up statements offered by an instructor can come in the form of feedback, recommendations, brainstorming, advice, and direct imperatives, as instructors guide students toward a new way of thinking and learning.

Mertz (2007a, 2007b) described the language and discourse used in law school classrooms to socialize students into future professions as attorneys. In Mertz's (1998) study of law school classroom dialogue, if a student answered a question one way, but the instructor wanted to hear the question answered in a different way, the instructor would redirect or re-contextualize the question. In one exchange,

The professor, after rephrasing a question several times (and receiving the same, "incorrect" answer - "no") tells the student, "Try yes." The student initially responds with silence. The professor repeats, rising intonation, added stress, "Say yes.” "Yes," says the student at last. 'Why?' the professor proceeds to attempt a continued dialogue (p. 329).

This exchange demonstrates instructors' guidance of a talk sequence, with follow-up statements that indicate an appropriate and expected language usage for the discussion. Classroom facilitators clearly have the ability to socialize norms of classroom behavior by the way that they speak and act.

The architecture and design studio classroom has also been studied as a site for socializing students into intellectual talk and into their future professions. Schön $(1983,1985)$ described the role of a reflective practitioner in demystifying some of the ambiguity that exists in many architecture and design classrooms, by providing regular feedback and oral critiques of work in order to improve its professional quality. Dannels (2005) found that through giving and receiving feedback in a design studio classroom, in themselves a form of follow-up statement, instructors socialize architecture students into "tribal" rituals that are unique to the profession. The design studio is thus somewhat of an incubator for students, providing them a laboratory in which their instructors provide follow-up statements, in the form of feedback and guidance during critiques. 
Design studios in such disciplines as architecture, graphic design, and engineering have long been regarded as sites for pre-professional socialization. Through oral presentations of student designs, and through listening to subsequent follow-up feedback from instructors, design studio students participate in classroom discourse that socializes them into their future professions (Dannels, 2009; Dannels, Gaffney, \& Martin, 2011) and into the intellectual talk that is used in the discipline. For example, some of the categories of evaluative follow-up statements exchanged in the design studio included brainstorming, making direct recommendations, commenting on the students' process, rendering judgments about the final product, expressing confusion, and questioning or interpreting concepts (Dannels, 2011). These forms of feedback, or follow-up statements for purposes of this analysis, regulate the flow of turn-taking in classroom discourse. In one design studio, instructors interjected such follow-up statements such as:

I think we need to explore other ways of creating dimension...Unless we see it, you might not see it...Sit down and be really quiet and listen...Be in a room with it. Play with it. Sit and look at it. What is it telling you? (Dannels \& Martin, 2008, pp. 143-147).

This give-and-take teaching and feedback philosophy is common in design disciplines, and provides useful support for analyzing how follow-up statements socialize intellectual talk in the classroom. Design professors, through their comments and suggestions, serve an important and necessary socializing and enculturating function for students and future professionals in the design field.

Clearly, the pre-professional experience and the graduate school experience socializes students into their future professions. Instructors have a unique opportunity to enculturate students into such professions as law, architecture and design, nursing (Holley \& Taylor, 2009), and other professions (Gardner \& Barnes, 2007). Because the socializing of intellectual talk in the classroom is such an integral part of the learning process, and has not been investigated beyond a generalized and descriptive level, more research into instructors' influence on instructional communication and student development is warranted.

\section{Methodology}

This article will now turn to methodology used in the analysis of follow-up statements and socializing intellectual talk in an undergraduate liberal arts community. This section will include a description of: 1) the research question, 2) the site and participants, 3) data collection and artifacts, and 4) analysis and coding.

\section{Research Question}

In light of the extant literature and current gaps in understanding about how instructors use followup statements to socialize students' use of intellectual talk in the classroom, this study posed the following research question:

RQ1: How do instructors use follow-up statements to socialize students' use of intellectual talk in the classroom? 


\section{The Site}

This site for this study is an undergraduate liberal arts learning initiative designed to promote innovation and creativity at a large, public, flagship, southeastern university. As part of the program, students complete two 100-level seminar foundation courses, then take 300-level thematic seminars, and complete their experience in the program with a 400-level capstone course. The capstone course integrates prior coursework into each student's development of an individual worldview. Learning outcomes of the program include: 1) developing intellectual breadth in the liberal arts, 2) critical reading and writing skills, 3) problem solving skills, and the ability to analyze and do research using data across the disciplines of the Arts and Sciences, 4) effective debate and discussion skills, and 5) a sense of community among freshmen who live together.

At the time of the study, about 250 students were enrolled in the program, many of whom lived in a residence hall provided by the program. Fourteen instructors, called senior fellows, taught in the program. Teaching assistants, called junior fellows, who are typically graduates of the program, assisted in teaching and facilitating the classes.

The classrooms observed at the site were roundtable classrooms, emphasizing face-to-face communication in small groups. The freshman seminar class took place in a large classroom that consisted of several semi-round tables connected into a full-circle in the middle of the room. The senior capstone class took place in a small seminar room that consisted of a large conference table with 10-15 chairs around it.

\section{Participants}

Freshmen and seniors enrolled in the liberal arts undergraduate initiative were a primary focus of this case study. The 18 students observed during this study ranged in age from 18 to 22 years of age. Each student was currently enrolled as an undergraduate student in either the freshman seminar class or in the senior capstone seminar. Of the ten freshmen, seven of them were female and three were male. Of the eight students enrolled in the senior seminar class, all of them were seniors; four of them were female and four were male. Overall, 11 of the 18 students participating in this study were female (61\%), and seven students were male (39\%). The students in this study came from a variety of backgrounds, though most grew up in southeastern states and described their socioeconomic backgrounds as middle class. Many of the students also reported growing up in Protestant Christian families and communities. Almost all of the students were Caucasian; one student was African American.

Each student in this study was minoring in liberal arts. Their chosen majors represented a diverse mix of disciplines: ten students were majoring in the college of arts and sciences (e.g., art history, english, french, history, international relations, political science, psychology, interdisciplinary studies, or theater and dance); six students were majoring in the college of science and engineering (e.g., biology, chemical engineering, computer science, or marine biology); one student was majoring in the college of commerce and business administration (e.g., management and marketing); one student was majoring in the college of social work; and one student was majoring in the college of human environmental sciences (e.g., communication disorders).

The primary instructor who was observed during this study has an academic home in the History department and also serves as a senior teaching fellow in the program. The assisting instructor who was also observed during this study completed the program while he was an 
undergraduate student at the university and has been an assistant instructor in the program since he enrolled in a graduate program.

All participants were provided with a description of the nature of the study and received a copy of an Institutional Research Board (IRB) information sheet, which they were asked to sign. They were informed that their identities would be protected and that all data would be used only for purposes of this project and that all records would be carefully stored during use and destroyed after use.

\section{Data Collection and Artifacts}

Data was collected in the proposed site from both a 100-level undergraduate initiative course and a 400-level capstone course. Artifacts included audio-recorded and transcribed classroom observations of eight class meetings of both the freshman and senior seminar classes.

The first classroom observation took place during the fourth or fifth week of the semester and continued until near the end of the semester. The audio-recorder was positioned as unobtrusively as possible and students were reminded to be as comfortable and natural as possible, even though they were being audio-recorded.

\section{Analysis and Coding}

Using Glaser and Strauss' (1967) grounded theory approach, this analysis coded for categories that emerged as relevant themes in reference to the research question. Grounded theory refers to an inductive process of uncovering theories and central concepts that are grounded in the information provided by participants (Strauss \& Corbin, 1998). As key concepts emerged from the data collected and analyzed during the study (Stake, 1995), participant perceptions of the classrooms were assessed inductively. Following this grounded theoretical approach, and the methodological strategies of Charmaz (2006), initial coding strategies included word-by-word and line-by-line coding of each incident as it happened.

The use of this coding method sought patterns and themes that emerged from classroom observations, fieldnotes, and recordings of classroom proceedings collected during the study. Analysis of these initial codes led to a systematic coding structure. Clustering is a method of coding in which the researcher groups the emergent themes into meaningful categories and systems (Marshall \& Rossman, 2011). Following Emerson, Fretz, and Shaw's (2011) instructions for writing ethnographic fieldnotes, the researcher in this study developed jottings into detailed notes of analysis, which were then open-coded, clustered, and thematized.

\section{Results}

By observing and analyzing classroom proceedings, this study looked for ways in which instructors' follow-up statements socialized students' use of intellectual talk. This section presents the emergent themes and findings from those observations.

\section{Emergent Themes and Findings}

Classroom observations were helpful in understanding how instructor's facilitation of classroom discussion challenged students to voice their thoughts about the readings in an intellectual and 
sometimes provocative way. Classroom discourse clearly demonstrated how students in the program have cultivated a sophisticated sense of how to critically evaluate what they have read.

\section{Construct of Classroom Discourse}

During the process of analyzing turn-taking during classroom discourse, it was apparent that students' knowledge about the readings, and their ability to articulate how well they understood them, was sophisticated. Many of the students in the class seemed highly familiar with the material and were evidently comfortable expressing their thoughts and ideas to the instructor. The instructor guided and facilitated the discussion as it unfolded. Examination of specific segments of turntaking showed a pattern of students consistently attempting to come to some form of understanding about a question, observation, or thought they were investigating out loud. Closer examination of this pattern of classroom discourse evolved into a construct describing the instructor's use of follow-up statements.

During the analysis of turn-taking segments, the third or fourth turn emerged as most interesting and led to a focus on instructor use of follow-up statements. The follow-up statement seemed to be the site in which the most remarkable amount of socialization occurred. As participants took turns during discussion, follow-up statements emerged as the central locations in discourse that provided a rich area for analysis of the socialization provided by the instructor. Follow-up statements were typically provided by the instructor as a student's turn was completed, or as a turn neared completion. As a regulator of linguistic discourse, turns tend to be taken at transition-relevant moments (Sacks, et al., 1974). In this study, these transitions took place when a pause would occur, or when students would look at the instructor or each other quietly for a brief moment. The third or fourth turn in a sequence of participant turn-taking was typically the site for an instructor's follow-up statement.

By analyzing the instructor's use of follow-up statements, this study identified four specific constructs of classroom discourse that socialized students' use of intellectual talk. These followup statements took the form of one of the following constructs or categories: 1) revoicing, 2) contextualization, 3) parallel elaboration, or 4) assistive elaboration (See Table 1). This results section will focus on each of these types of follow-up statements as they occurred in the observations and the discussion section will explain these findings.

Table 1. Socializing intellectual talk: Construct of instructor use of follow-up statements

\begin{tabular}{|l|l|}
\hline Type & Definition \\
\hline 1. Revoicing & $\begin{array}{l}\text { Restates students' ideas in different } \\
\text { terms. }\end{array}$ \\
\hline 2. Contextualization & $\begin{array}{l}\text { Connects students' ideas to } \\
\text { conventional knowledge and broader } \\
\text { perspective. }\end{array}$ \\
\hline 3. Parallel Elaboration & $\begin{array}{l}\text { Extends students' thinking; repeats } \\
\text { words used by the student. }\end{array}$ \\
\hline 4. Assistive Elaboration & $\begin{array}{l}\text { Student requests the help of the } \\
\text { instructor; the instructor grants } \\
\text { assistance. }\end{array}$ \\
\hline
\end{tabular}

Journal of the Scholarship of Teaching and Learning, Vol. 17, No. 1, February 2017. josotl.indiana.edu 
Revoicing. O’Connor and Michaels (1993) defined revoicing as a linguistic structure, often used by instructors, to bring students into the process of intellectual socialization. Through revoicing, the instructor purposefully and skillfully creates a participation framework for talk by restating students' ideas with different terminology. Revoicing challenges the instructor to adapt simultaneously to the unfolding of participant structure within the classroom discussion. In short, the instructor and student jointly construct the lesson. Erickson's (1982) work showed that instructors are in a state of constant activity: initiating, responding, and evaluating, sometimes on a minute-by-minute basis. In short, revoicing creates a participation framework as the instructor adapts to the discussion while it unfolds.

During the following excerpt of classroom discussion, the assistant instructor asked students to describe altruism, which related to the reading for the day. As a student summarized what she understood from the reading, the assistant instructor revoiced what he was hearing in different terms. For example, the classroom discourse included the following excerpt,

Student: Do you think that there are, like, different, like, forms of altruism? 'Cause I...think...there can be something like, "I'm going to give the hobo money, because I feel sorry for him, and I'm gonna feel good about myself.” And then, there's like, “I'm gonna take this bullet for you.” And then there's like, I think they're different forms, so....

Instructor: But, I...don't you feel like giving people resources is more of a compassion and hospitality thing, and not necessarily... I guess I wouldn't define that as altruism. I think there are other words that are more appropriate to describe that kind of symptom.

Student: $\quad$ Then, wouldn't you say that animals are altruistic? Because most of the time they're just providing resources for each other, versus like, sacrificing themselves for another one.

Instructor: So, I don't think it's an altruism thing...[In] most ant societies, it's the old women that go off to play scouts and to fight in the war...they're sacrificing their lives as the scouts on the front lines, because they don't have anything left to give to society. Does that make sense?

Student: $\quad$ So, do you see a clear difference between altruism and compassion, altruism and kindness? Because...I've lumped 'em together, you know like, an act of kindness and an act of compassion is probably going to be altruistic behavior...

Instructor: Right, I think you can talk about altruistic behavior...I think there's a difference, when the word is used as the adverb or adjective and you're describing something, and when you're talking about it as an action itself...Y You're saying, this has qualities that are reminiscent of altruism, but it is not...you're not laying down your life for somebody.

“Altruism” p. 1 
Here, the student described what she believed to be a definition of altruism. The instructor overlapped with the student's turn, revoicing or restating the thought with a different vocabulary. What at first appeared to be a corrective statement, guiding the student towards a "correct" answer, was the assistant instructor's attempt to restate the student's idea in different words. This type of cascading or dovetailing during turn-taking shows that the assistant instructor does not necessarily want to give a "correct" answer, because perhaps none exists. His follow-up statements indicated that he wished to provide other words to describe the same concept.

The instructor's revoicing of the student's responses to the question introduced a potential controversy into this discussion, to which the student responds by hedging. The student used several upward vocal intonations and inflections, verbal pauses such as "like" and "you know," and descended in vocal volume as her thought phrase came to an end. After this brief hedging, the instructor continued in explanation and elaboration, to repair any sense of controversy that loomed in this discussion.

Contextualization. Contextualization occurs when an instructor attempts to place a student's ideas into a larger perspective during a follow-up statement. To contextualize, the instructor links students' experiences and inventions with conventional knowledge categories of the wider world. This context gives the student a new direction in his or her thinking. The instructor in this particular study was particular skilled at providing stories and anecdotes to contextualize student responses.

During the following excerpt of classroom discussion, the instructor asked the students what they thought William Shakespeare was trying to communicate in the play King Lear. During this exchange, the instructor shared some of the historical context relevant to the time period in which the play was written, in an attempt to give a broader context for the message of Shakespeare's play. The discussion unfolded in this way,

Student 1: So, do you think Shakespeare would have been making the argument that the divine right of kings is more or less illegitimate at a time when most monarchs in Europe thought that was completely true?

Student 2: $\quad$ Yeah, but you can't outright say that or you'll get, “Off with your head."

Student 3: That's what I took from the whole story in general.

Instructor: I think that you're heading in a very useful direction here with discussing the whole issue of the divine right of kings because when was the play written?

Student 1: $\quad$ 1607, I think.

Instructor: ...This is during the reign of James VI of Scotland...it's at this [tumultuous] time during James' reign that we got King Lear. So now, can William Shakespeare write a satire about what had just happened in England? No, he cannot...so you've got the divine right of kings represented by Lear and then you've got a kind of, don't you get a kind of Machiavellian world perspective with Goneril and Regan?

“King Lear” p. 4 
In this exchange, the first student described, and perhaps questioned, Shakespeare's intentions by using the term "divine right of kings." Two subsequent turns by fellow students was beginning to take the discussion in a different direction. In order to direct the discussion back to the idea of the divine right of kings, the instructor asked about the historical context of the play. In this discussion, the instructor contextualized this reaction, by stating that the student's description of the divine right of kings was correct, as represented through the character of King Lear, but that Shakespeare was also trying to communicate a Machiavellian worldview through the characters of Goneril and Regan. This contextualization served as another example that the instructor is not necessarily interested in providing "correct" answers, rather he encourages students to place their ideas in context with the author's supposed intent.

Parallel Elaboration. In their study of classroom discourse, O’Connor and Michaels (1993) described the strategic value for an instructor to induct students into a discourse community, by encouraging them to "adopt roles in the ongoing practices that she [or he] wishes them to develop" (p. 325). Parallel elaborations allow an instructor to reintroduce a proposition made by a student in a slightly altered or clarified form. A parallel elaboration extends a student's thinking by reinforcing some of the words used by the student, while introducing a new way of thinking about the idea or observation the student proposed.

During a discussion about Darwin and evolution in the freshman class, for example, a student inquired about whether or not domesticated animals maintain the characteristics of their parent genes. The assistant instructor elaborated briefly, and then provided a parallel elaboration, using some of the same thoughts, words, and ideas provided by the student. The following exchange took place during classroom discourse,

$\begin{array}{ll}\text { Student: } & \begin{array}{l}\text {...which I was kinda confused about, 'cause if they descended from } \\ \text { wolves, they're not gonna go back to being wolves...like a } \\ \text { chihuahua? } \\ \text { (laughter) }\end{array} \\ \text { Class: } & \begin{array}{l}\text { So, I actually brought an example to class about that... In this article } \\ \text { about Russian silver foxes...[They] looked more like wolves than } \\ \text { they did foxes, when they started... }\end{array} \\ \text { Student: } & \begin{array}{l}\text { So, the chihuahua doesn't necessarily go back to the... } \\ \text { Instructor: }\end{array} \\ \text { Student: } & \begin{array}{l}\text { Maybe not the chihuahua turning into a wolf... } \\ \text { Instructor: }\end{array} \\ & \text {...but, so they were breeding for tameability. }\end{array}$

In this excerpt, the assistant instructor underscored some of the same words, either verbatim or with use of synonyms, as used by the student. For example, the assistant instructor repeated the student's use of the words "chihuahua" and "wolf," and responded directly to her question by referencing an article that was relevant to her question. The student and assistant instructor seemingly collaborated together on this parallel elaboration about Darwin's beliefs of genetic survival of the fittest as it related to domesticated animals bred for tameability.

Assistive Elaboration. Similar to the parallel elaboration, assistive elaborations follow up on a student's previous utterance, in order to extend or introduce a new way of thinking for the student to consider. With assistive elaborations, the student has requested the help of the instructor in fleshing out an idea. Gumperz (1990) has explored the idea that a speech community is created 
when individuals who have a common history, and have undergone similar communicative experiences, employ rhetorical strategies that serve as a badge of membership. In the classroom I observed, the professor had taught many of the students before, which set up an atmosphere of enough familiarity for students to make themselves vulnerable in asking for help as they talk about their insights and observations out loud.

During a discussion about Fydor Dostoevsky's The Grand Inquisitor, students in the senior class responded to the instructor's question about the cynical nature of one of the main characters in the parable. The instructor's follow-up statements in this discussion were clearly geared toward a student's request for assistance in understanding the cynicism of one of the main characters, Ivan. The discussion occurred in this way,

Instructor: Ivan talks about horrible things that happened, right? And it's his awareness of that, is it not, that gives him his cynical sense of life, don't you think...

Student: $\quad$ Yeah, he brings up...basically, a big part of his argument and a big source of his skepticism, uh, is the problem of evil...you know...if God is benevolent, why...

Instructor: All powerful, why do people, good people, die?

Student: $\quad$ Yeah...but uh, yeah. And it's a good problem. And it's a relevant problem...

Instructor: But the grand inquisitor has a response to that, doesn't he?

Student: $\quad$ Yeah, I think so. He says, uh, uh, is it the -- does he respond to that with the --

Instructor: He says, "Love. Love a man even in his sin. Love all of God's creation. Love everything. Love the animals."

“The Inquisitor," p. 1

In this excerpt, the student asked for assistance in understanding Ivan's cynicism and skepticism. The instructor granted this assistance by quoting a passage from the reading, clarifying how another of the main characters was responding to Ivan's cynicism. This assistive elaboration helped the student to elaborate on his interpretation of Dostoevsky's writings on good and evil.

During data analysis, instructor's effective facilitation of discourse and dialogue allowed this four-part repertoire to emerge as relevant in the findings. The instructor's use of follow-up statements showcases how discourse socializes students into intellectual talk. Studying a knowledgeable and veteran instructor certainly enhanced this process of analysis. Having access to a roundtable learning space that clearly paved the way for such lively dialogue also allowed this four-part construct to emerge. The implications of these findings will be discussed in more detail in the discussion section.

\section{Discussion}

This article will now turn to a discussion of use of instructor follow-up statements and socializing intellectual talk in this undergraduate liberal arts community. This section includes a discussion of findings, practical recommendations, and suggestions for future research.

The research question in this study asked about the ways in which instructors' follow-up statements socialized students' use of intellectual talk. This section presents the themes and 
findings from those observations. The current study supplements findings in past studies by providing a typology of classroom discourse and describes how the categories of the discourse typology are evidence of the socializing of intellectual talk.

Classroom observations revealed several patterns about how classroom discourse occurred in this study of a liberal arts classroom. Instructor facilitation of discussion in this particular classroom was unique in its ability to challenge students to investigate, and sometimes interrogate, their own ideas and thoughts. In each class, the instructor engaged students in active discussion about the readings for the day. By assisting students in elaborating their own ideas, and helping them to restate or contextualize their ideas, the instructor elevated students' ability to articulate what they were thinking.

While past studies of classroom discourse in the design profession have categorized instructors' feedback statements, or follow-up comments, as brainstorming, free-associating, making direct recommendations, commenting on students' process, rendering judgments about the final product, expressing confusion, and questioning or interpreting concepts (Dannels \& Martin, 2008; Dannels, 2011), this study categorized instructors' follow-up statements in a way that is unique to socializing intellectual talk in the classroom. Specifically, this study identified four constructs of classroom discourse that socialized students' use of intellectual talk. Follow-up statements took the form of one of the following: a) revoicing, b) contextualization, c) parallel elaboration, and d) assistive elaboration. This socialization both integrated students into the sense of community in the program, and prepared them for future professional roles in which they will likely use the same intellectual talk.

In particular, the instructor's use of follow-up statements did not apparently seek to provide "correct" answers, but encouraged students to place their ideas in context with the supposed intent of an author or playwright. In instances in which the instructor's follow-up statement introduced any potential embarrassment or controversy for a student, the instructor continued explaining and elaborating in order to repair any sense of hedging or controversy that may have been perceived by the student. In this study, follow-up statements were clearly used to guide students in their own thinking and assist them in grounding their utterances in the course readings.

An important conclusion drawn from the findings in this analysis of classroom discourse is that both the instructor and students seemed to collaborate in creating shared knowledge in this liberal arts classroom. In this supportive climate, where they were reportedly comfortable sharing their ideas openly, students were able not only to socialize into the program, but also into their future chosen professions. These findings support what is already known about the importance of socialization to student development (Weidman, Twale, and Stein, 2001) and the importance of enmeshing students into their future chosen careers (Jablin, 1982; Schein, 1968; Van Maanen \& Schein, 1979; Weick, 1995). Developing the intellectual talk necessary to perform well academically will also help students develop the skills necessary for success in future life and work.

Another conclusion drawn from the findings is that students clearly became enmeshed in the program's community and were able to demonstrate this membership through their use of intellectual talk. As one senior stated, when freshmen step through the doors of Oliver-Barnard Hall, they are hailed by upperclassmen for being in the "big leagues." According to Gumperz (1990), individuals who have a common history and undergo similar experiences within a certain institutional network earn a badge of membership. In this study, it was clear that the instructor created a supportive climate that not only produced positive cognitive results, but also created a community of support among members of the class. Before class, on more than one occasion, 
students offered verbal support and advice about their studies and about the experience of being in the program. These in-between times provided some of the best examples of socialization into intellectual talk and into future professions that will likely demand the same ability to integrate into the community.

\section{Recommendations for Practitioners}

This study demonstrated that instructors who provide thoughtful follow-up statements during classroom discourse assist students in thinking about and articulating their ideas in a way that prepares them for future life and work. Students who receive active mentoring and coaching from an instructor during classroom discourse actively particulate in classroom discourse.

One way for instructors to increase the quality of their follow-up statements is to prepare discussion questions in advance. Thoughtful preparation of questions allows instructors to think through the myriad ways in which students may respond. In doing so, instructors are able to formulate ways in which to revoice, contextualize, and/or assist in the elaboration of a variety of student responses. Allowing adequate class time for this discussion is essential.

Facilitating student-centered classroom discourse requires instructors not only to be flexible in their instructional practices, but also familiar with their course content. Professional development programs in which instructors have an opportunity to refresh or increase their content knowledge in specific areas could improve their facilitation of follow-up statements in the classroom.

Finally, instructors can benefit greatly from observing others' use of effective questioning techniques during classroom discourse. Observing exemplary instructors (e.g., live, recorded, webcasts) offers vicarious learning experiences and promotes a conditioning response to improve future teaching. In addition, administrators can provide support for instructors to observe the instructional practices of their peers and to help form a community of mentors. These experiences provide instructors with resources to strengthen their classroom facilitation, to provide active and thoughtful follow-up statements during classroom discourse, and thereby to prepare their students for future life and work.

\section{Future Research}

This article discussed the four-part construct of classroom discourse that was introduced in the findings. As a means of identifying and describing the socialization of intellectual talk in the classroom, this construct was central to this study. However, this construct needs to be tested further by studying other instructors to see what other codes might emerge in the data. Other instructors may approach turn-taking and participant framework of discourse differently. It will be relevant in this future research to consider the discipline in which the instructor teaches. A comparative study of an instructor in the business school and an instructor in a science and engineering school, for example, may produce very different results in expanding the construct proposed in this study.

Teacher behavior influences student behavior (West \& Pearson, 1994). Future studies should continue to investigate all the ways in which classroom discourse can benefit the learning experience. The current study, for example, did not employ the use of quantitative measures or instructor or student perceptions and responses to the use of follow-up statements in classroom 
discourse. Future studies could diversify the analytical tools used to understand follow-up statements and intellectual talk in the classroom.

Finally, the roundtable nature of this classroom may have influenced the level of student investment in classroom dialogue and discourse. Because the influence of the learning space in which this analysis took place was not addressed in this study, another future study could investigate its role in students' active participation in intellectual talk and instructors' willingness to socialize intellectual talk in the roundtable classroom as opposed to a traditional classroom of desks in rows.

\section{Conclusion}

By investigating student-teacher sequences of talk and turn-taking in a liberal arts classroom, this case study adds to current research on classroom discourse, socialization, and observational research. As a culture complete with its own unique language system, the classroom provides a space in which instructors and students can freely engage in dialogue. Instructors' facilitation of classroom discourse is essential to teaching and learning.

By facilitating classroom discourse, instructors socialize and assimilate students into competent and correct usage of intellectual talk. Investigating instructors' critical role in guiding students toward the attainment of these language usage skills is essential to understanding and improving students' ability to learn and develop.

\section{Acknowledgments}

I am most grateful to Dr. Karri A. Holley for the guidance and instruction that made this study happen. Many thanks also go to my department chair, Dr. Beth S. Bennett, whose encouragement and support was instrumental during the preparation and completion of this publication.

\section{References}

Cazden, C. B. (1986). Classroom discourse. In M. Wittrock (Ed.), The handbook of research on teaching (pp. 432-463).

Charmaz, K. (2006). Constructing grounded theory. London: Sage.

Dannels, D. P. (2005). Performing tribal rituals: A genre analysis of “crits” in design studios. Communication Education, 54(2), 136-160.

Dannels, D. P. (2009). Features of success in engineering design presentations: A call for relational genre knowledge. Journal of Business and Technical Communication, 23(4), 399-427.

Dannels, D. P. (2011). Relational genre knowledge and the online design critique: Relational authenticity in preprofessional genre learning. Journal of Business and Technical Communication, 25(1), 3-35.

Dannels, D. P. \& Martin, K. N. (2008). Critiquing critiques: A genre analysis of feedback across novice to expert design studios. Journal of Business and Technical Communication, 22, 135-159. 
Dannels, D. P., Housley Gaffney, A. L. \& Martin, K. N. (2011). Students' talk about the climate of feedback interventions in the critique. Communication Education, 60(1), 95-114.

Emerson, R. M., Fretz, R. I., \& Shaw, L. L. (2011). Writing ethnographic fieldnotes (2 ${ }^{\text {nd }}$ ed.). Chicago: University of Chicago Press.

Erickson, F. (1982). Classroom discourse as improvisation. In L. C. Wilkinson (Ed.) Communication in the classroom. New York: Academic.

Gardner, S. K. \& Barnes, B. J. (2007, July/August). Graduate student involvement: Socialization for the professional role. Journal of College Student Development, 48(4), 1-19.

Glaser, B. G. \& Strauss, A. L. (1967). The discovery of grounded theory: Strategies for qualitative research. Chicago, IL: Aldine Publishing.

Gumperz, J. (1990). Speech community in interactional perspective. In H. Parret (Ed.), La communaute en parole: Communication, consensus, ruptures. Translated: The community in word: Communication, consensus breaks. Brussels: Mardarga.

Holley, K. A. \& Taylor, B. J. (2009). Undergraduate student socialization and learning in an online professional curriculum. Innovations in Higher Education, 33, 257-269.

Jablin, F. M. (1982). Organizational communication: An assimilation approach. In M. E. Roloff \& C. R. Berger (Eds.), Social Cognition and Communication, 255-286.

Lindsay, J. S. (1990). Classroom discourse analysis: A review of the literature with implications for educational evaluation. Journal of Research and Development in Education, 23, 107-116.

Marshall, C. \& Rossman, G. B. (2011). Designing qualitative research (5 ${ }^{\text {th }}$ ed.). Los Angeles, CA: Sage.

Mehan, H. (1979). Learning lessons: Social organization in the classroom. Cambridge MA: Harvard University Press.

Mertz, E. (1998). Linguistic ideology and praxis in U.S. law school classrooms. In Schieffelin, B., Woolard, K., \& Kroskrity, P. (Eds.), Language ideologies: Practice and theory (pp. 149-162). Oxford University Press.

Mertz, E. (2007a). The language of law school: Learning to "think like a lawyer." Oxford University Press.

Mertz, E. (2007b). Legal language and American law: Authority, morality, and linguistic ideology. In The language of law school (pp. 207-308). Oxford University Press. 
O’Connor, M. C. \& Michaels, S. (1993). Aligning academic task and participation status through revoicing: Analysis of a classroom discourse strategy. Anthropology and Education Quarterly, 24(4), 318-335.

Sacks, H., Schegloff, E. A., \& Jefferson, G. (1974). A simplest systematics for the organization of turn-taking for conversation. Linguistic Society of America, 50(4), 696-735.

Schein, E. H. (1968). Organizational socialization: Making sense of the past and present as a prologue for the future. Industrial Management Review, 9, 1-16.

Schön, D. (1983). The reflective practitioner: How professionals think in action. New York: Basic Books.

Schön, D. (1985). The design studio: An explanation of its traditions and potentials. London: RIBA.

Stake, R. (1995). The art of case study research. Thousand Oaks, CA: Sage.

Strauss, A. \& Corbin, J. (1998). Basics of qualitative research: Techniques and procedures for developing grounded theory ( $2^{\text {nd }}$ ed.). Thousand Oaks, CA: Sage.

Van Maanen, J. \& Schein, E. H. (1979). Toward a theory of organizational socialization. Research in Organizational Behavior, 1, 209-264.

Weick, K. E. (1995). Sensemaking in organizations. Thousand Oaks, CA: Sage.

Weidman, J. (1989). Undergraduate socialization: A conceptual approach. In. J. Smart (Ed.), Higher education: A handbook of theory and research, V (pp. 289-322). New York: Agathon.

Weidman, J., Twale, D., \& Stein, E. (2001). Socialization of graduate and professional students in higher education: A perilous passage? ASHE-ERIC Higher Education Report, 28. San Francisco: Jossey-Bass.

West, R. \& Pearson, J. C. (1994). Antecedent and consequence conditions of student questioning: An analysis of classroom discourse across the university. Communication Education, 43(4), 299311. 